\title{
FORMING THE FUTURE LAWYERS' COMMUNICATIVE COMPETENCE: THE EXPERIENCE OF HIGHER EDUCATION IN UKRAINE AND GERMANY
}

\begin{abstract}
In the article the state of forming of communicative competence of future lawyers in higher education of Ukraine and Germany is analyzed. There is made the comparative description of preparation of the students of law faculty with an accent on forming of communicative competence on the example of the University of modern knowledge (Ukraine) and Frankfort university is named after Goete (Germany).

It is drawn the conclusion, that the structure of professional preparation of future lawyers is folded educational and cognitive, research constituents, and also productive practice. A main place is taken to conception of communicative preparation of the future lawyers, the essence of it consists in integration of the special courses of the special and professional disciplines, in continuous perfection of skills of the verbal and writing broadcasting, receptions of analytical mental work, that need knowledge. It is also outlined the aim of productive practice of future lawyers in Ukraine that begins from the second course: the forming of professional abilities and skills of acceptance of independent decisions; the education of necessity systematic to proceed the knowledge, to promote a legal culture and professional legal consciousness; to teach to apply knowledge in practical activity. In Germany the practice for future lawyers begins from the first course and lasts two years in legal establishments (from civil cases, court from criminal cases or office of public prosecutor, administrative and managerial establishments, advocacy). The sign line of studies is an active collaboration with the faculties of law of the foreign states. All these factors assist the forming of communicative competence of lawyers.

Key words: the future lawyer, forming, the communicative competence, the professional preparation, the educational and cognitive preparation, Ukraine, Germany.

\section{INTRODUCTION}

The world tendencies of globalization and integration, social and economic transformations in Ukraine at the beginning of XXI century, the change of knowledge-centric paradigm on educationally oriented, an axiology was stipulated by quality changes in professional preparation of future lawyers with an accent on forming of communicative competence.

The development of new facilities of communication, a process of legislation adaptation of Ukraine to the requirements of the European legislation is those factors, that attract considerable attention to the questions of professional communication in the field of a right both abroad and in Ukraine. On such conditions the problem of forming of professional communicative competence becomes one of important problems of modern higher education.
\end{abstract}

\section{THE AIM OF THE STUDY}

In the article we analyze the state of forming of communicative competence of future lawyers in higher education in Ukraine and Germany. 


\section{THEORETICAL FRAMEWORK AND RESEARCH METHODS}

Taking into account modern realities of world development, social order to the system of higher legal education is orientated the preparation of future lawyers on the standards of international education, leaning on such legislative and normative base: the National doctrine of development of formation of Ukraine in XXI century, Law of Ukraine "On education", Law of Ukraine "On higher education", documents of the UNO, Advice of Europe, The international association of lawyers, the blighty deontilogical codes, the normative acts that regulate the activity of legislators. In the last decade of century is updated the attention to the communicative constituent of legal activity. Among the Ukrainian and foreign scientists who investigate this direction are, - S. Husarev, O. Tykhomyrov, V. Bihun, D. Fiolevskyi, M. Anufriev, K. Volker, M. Dzh. Bonel, Kh. Ketts, Rene de Hrut, Dzh. Merimen, B. Futei and others.

The research methods we used are: theoretical analysis, synthesis, the method of studying educational and historical documents.

\section{RESULTS}

The analysis of the scientific sources, which was realized by us, shows the legal system as Ukraine and Germany is based on confession of law the basic source of right. Development of right comes true by codification. Basic legal concepts form an only legal language, Ukrainian and German legal systems are followed by the legal acts of Constitution, civil, civil procedure, criminal, criminal procedure codes. The basic fields of law (constitutional, administrative, labor, civil, criminal and two judicial fields) coincide in these countries. And such concepts as, responsibility, law, subordinate legislation, court decision, crime, offence and many others have generally or similar meaning (Андрощук, 2006).

For a lawyer who works in the system "human person", extraordinarily actual communicative constituent. Inexact or false usage of terminology, logical and grammatical mistakes, inaccuracies meaningful in forming of legal norms, that brings to their diffuse or multiple-valued interpretation, are the impermissible phenomena in a legislative language. A modern lawyer in Ukraine must appear before national society and as a highly educated specialist, and as personality who is on the basis of the realized capture of specific facilities of national legal terminology taking into account Ukrainian-language norms and facilities able to fold bills, carries out business correspondence, prepares protocols, resolutions, lawsuits, live performances, avoids interference errors, produces skills of self-control and self-correction with support on language norms and practice.

In professiogram of legal professions (Ануфрієв, 2003) are outlined the requirements to communicative qualities of lawyer depending on specialization. In particular, it is marked that a profession of judge is one of the most difficult legal professions. Exceptionally a judge gets a right on realization of justice. Professional activity of judge is public, he must to know a right, psychology of communication with colleagues, clients, able attentively to hear out witnesses, experts. The ability to listen an interlocutor, to communicate, to give exhaustive and direct answers is one of descriptions of professiogram judge.

In Germany legal education is largely concentrated on the role of judge, the term of his stay in commission begins from the moment of completion of studies. In German a judge prevails in a trial and plays an important role. At interpretation of constitutional decision of department judicial, as entrusted to the judges (at. 92 the Basic law) it is talked in Comment, that this legal provision spreads to the circle of persons "that engage in an anxiety about a right" (Rechtspleqe), and, in its turn it is examined as "state efforts on realization of justice (Gerechtiqkeit) or providing of the legal world". An author of the Comment to Law of the judicial system, Otto Kyssel, asserts that such approach is up to the 
views of the famous German professors such as: Hans Wolff, Otto Bachov, Theodor Maunz, Eberhard Schmidt-Assmann and others. The circle of persons who is in the marked space is determined so: judges, public prosecutors, auxiliary workers of judges, advocates and notaries who participates in execution state tasks (Kissel, 1981).

Let's analyze the features of professional preparation of future lawyers in Ukraine and Germany. A basic normative document that determines organization of educational process in higher legal educational establishments of Ukraine and Germany is a curriculum. We will give the analysis of curriculums of faculties of law of the University of modern knowledge (Kyiv), Vinnytsia branch of the University of modern knowledge, Frankfort university speciality 6.060100 Jurisprudence. The conducted analysis certifies that curriculums are concluded on the basis of the educationally-professional program and structurally and logical chart of preparation. A list and volume of normative and selective educational disciplines, sequence of their study, certain forms of realization of lessons and their volume, chart of educational process, form and facilities of realization of current and final control are certain in documents.

The structure of professional preparation of future lawyers is folded educationalcognitive, research to composition, and also productive practice. Research part is organized educational-research and scientifically-research activity. Practical part is presented by productive practice. An educator constituent is inalienable part each of afore-named and realized both in an audience and extracurricular forms of work. The aim of professional preparation of future lawyers - at harmonious interconnection and optimal correlation of subsystems forms the positive motivation to professional activity, to assist the capture of common cultural and special legal knowledge a necessary volume, by professional abilities and skills of jurisprudence.

Integrity of professional preparation of the future lawyers is predefined harmonious interconnection between its subsystems and components. In the article is accented the attention on educational-cognitive preparation, and also on the features of productive practice. In particular, humanitarian preparation is sent to the capture of the national culture, capture of philosophical world view and laws of cognition of the surrounding world, deepening of knowledge of the mother and foreign tongues. The naturally-scientific preparation is a base of the system link in forming of professional knowledge and abilities. The general legal preparation embraces the complex of legal knowledge, abilities and skills for providing of development of legal culture and consciousness of both person and society on the whole. A professionally-communicative constituent comes forward as a through link.

As an analysis of curriculum of faculty of law of Vinnytsia branch of the University of modern knowledge certifies, with the aim of forming of communicative competence future lawyers seize in disciplines from a civil and domestic law, criminal right, international law, procedural criminal law, theories of the state and right students such themes: concept of category of official language; language as means of realization of offences; language as means of influence(legitimate and illegal facilities), broadcasting as means of transmission, receipt and fixing of information(code and decoding of speech information, stages of code of the verbal broadcasting; speech markers of shows and others like that). "Judicial rhetoric" as educational discipline is called to prepare a future lawyer to work with an audience, to teach to come forward, to convince, to take facilities words, to conduct a structural dialogue and polylogue. The aim of study of discipline "Legal deontology" - to give to the studentslawyers the basic knowledge about requirements to professional and ethic qualities of legislator, to acquaint with the specific of the social adjusting of their professional activity, 
expose the deontological norms of culture, to teach the students to understand in the structure of right, facilities of legal technique and to decide the question of legal qualification on this basis. The aim of course "Ukrainian" is a professional acquaintance of students with the theoretical and practical aspects of Ukrainian's structure in the field of professional communication, forming of communicative skills of future specialists. These disciplines are possible to count the modules the "Language competence: maintenance and ways of forming", "Feature of preparation and realization of acts of language communication", "The public speaking as variety of verbal language", "Specific of language embodiment of information in the field of professional communication", "Text as means of different styles communication", "Business document as basic type of writing form of language of professional communication". However the offered program does not provide forming of such important for a lawyer abilities, as ability to interpret a law, interpret business facts, conduct a professional dialogue as judicial action. The aim of discipline teaching is "Legal scientific discipline of documentation and bases of modern office work" is a professional acquaintance of students with the theoretical and practical aspects of structure of scientific discipline of documentation and office work documentation on the modern stage of its functioning, forming of proof professional and communicative skills in the field of business communication.

We will consider the curriculum of faculty of law of Frankfort university is named after Goete. A Professionally-communicative constituent pierces to both the duty and the special disciplines. To obligatory disciplines belong civil, criminal, public, judicial law in connection with the corresponding divisions of European right, methodology right, the bases of the theory of right, the philosophy of right, the sociology of right, the history of right and constitution. The stage of the special preparation lasts in sixth - eighth semesters and includes, in particular, the theory of leading to, legal hermeneutics, legal logic, sociology of right, legal ethics, legal psychology.

As an analysis of literary sources testifies (Kroschel, 1994; Kissel, 1981), in Germany the communicative preparation of future lawyers is one of important aspects of professional preparation. Essence of conception of communicative preparation of future lawyers consists in integration of the special courses of the special and professional disciplines, in continuous perfection of skills of the verbal and writing broadcasting, receptions of analytical mental work, that need to know languages. All systems of teaching is careful thought out thus, to form and develop organizational, pedagogical, communicative flairs for future lawyers. The considerable attention is spared to the studies of professional German. The language courses operate at the universities. In particular for foreigners in higher educational establishments of legal profile courses function "German for lawyers".

We will find out also a role and place of productive practice in forming of professional communicative competence of future lawyers. Aim of practice : capture students by modern methods, by the forms of organization of labor in industry of their future profession; the students of professional abilities and skills of acceptance of independent decisions have forming; education of necessity systematic to proceed in knowledge, to promote a legal culture and professional legal consciousness; to teach to apply knowledge in practical activity, to purchase experience. Task of practice: to acquaint students with practice of work, experience of organization of legal work in organization, practice of application of current legislation of Ukraine, organization of legal education and studies; to collect and generalize practical material for writing of term (diploma) paper, to purchase skills of realization of research work. 
The order of realization of practice is certain Department of education and science of Ukraine and university. According to a curriculum the students of daily and in absentia forms of studies pass productive practice on the second, third, fourth courses; and students of in absentia form of studies - on the last course. Before diploma practice students pass the last course of studies.

The analysis of current documentation of practices was witnessed also, that in the system of productive practices do not enough realized in the principle of continuity, oriented to forming of professional communicative competence of future lawyers, its progressive advance and perfection from a course to the course. Among reasons of such state is an unexhausted mechanism of taking into account of individual features, interests of students, intercommunication between an university and legal establishments practice is conducted in that .

In Germany practice for future lawyers begins after the theoretical course of studies, that lasts 3,5, and handing over of the first state examination, and lasts two years in "obligatory" legal establishments and establishments at choice. To "obligatory" belong: general court from civil cases, court from criminal cases or office of public prosecutor, administrative and managerial establishments, advocacy. In these establishments practice lasts to three months, more than time taken on practice after the choice of future lawyer. After practice students pass the second state examination.

The sign line of studies of lawyers in Germany is close connection and active collaboration with the faculties of law of the foreign states. Many German universities have partner agreements with the universities in Europe, America, Asia about an exchange students.

\section{CONCLUSIONS}

So, it is possible to draw a conclusion, that the state of forming of communicative competence of future lawyers is both in Ukraine and in Germany has common feature. Firstly, the legal system of both Ukraine and Germany is based on confession of law the basic source of right, both the fields of law and basic concepts coincide for this reason. Secondly, a basic normative document that determines organization of educational process in higher legal educational establishment in Ukraine and Germany is a curriculum. The conducted analysis of curriculums of faculty of law of University of modern knowledge (Ukraine) and Frankfort university (Germany) is shown that they are based of the educationally-professional program, structural and logical chart of preparation. Thirdly, the structure of professional preparation of future lawyers is folded educational-cognitive, research and also productive practice. Fourthly, a main place is taken to conception of communicative preparation of future lawyers, the essence of that consists in integration of the special courses of the special and professional disciplines, in continuous perfection of skills of the verbal and writing broadcasting, receptions of analytical mental work, that need knowledge. All these factors assist of forming of communicative competence of future lawyers.

\section{REFERENCES}

1. Андрощук, А. (2006). Професійна підготовка юристів у Німеччині [The professional preparation of lawyers in Germany]. Київ (in Ukrainian).

2. Ануфрієв, М. (2003). Професіографічна характеристика основних видів діяльності в органах внутрішніх справ Украӥни (кваліфікаційні характеристики професій, професіограми основних спеціальностей) [Professiographic description of basic types of 
activity in the organs of internal affairs of Ukraine(qualifying descriptions of professions, professiogram of basic specialities)]. Київ: МВС України (in Ukrainian).

3. Бігун, В. (2004). Юридична освіта в Україні та Німеччині [Legal education in Ukraine and Germany]. Київ: Видавнича організація «Юстіан» (in Ukrainian).

4. Гусарєв, С. (2006). Юридична деонтологія (Основи юридичної діяльності) [Legal deontology (Bases of legal activity)]. Київ: Знання (in Ukrainian).

5. Kroschel, Meyer-Goflner/ (1994). Die Urteile in Strafsachen [The opinions in punishable objects]. Munchen: Vahlen (in German).

6. Kissel, O. (1981). Gerichtsverfassungsdesetz [The law of legal procedure]. Kommentar [comment]. § 49 (in German).

7. Reform der universitaren Iuristenausbildund [The reforms of the lawyers' teaching in universities]. (1999). Das "Hadenburger Manifest" [Hadenburger Manifest]. Beilagenheft, No 2, p. 30-31 (in German).

8. Sattelmacher, S. (1994). Bericht, Gutachten und Urteil. Eine Einfuhrung in die Rechtspraxis [The lecture, opinion and reason. The direction of the lawyers practice]. Munchen: Verlad Franz Vahlen (in German).

9. Офіційний сайт Міністерства освіти і науки України [The official site of The Ministry of education and science of Ukraine]. Retrieved 11.09.2014 from: <http: // www. mon. gov.ua/1769 - zatverdgeeno-umovi-priy> (in Ukrainian).

10. Сайт Франкфуртського університету імені Гьоте [The site of the Frankfurt university is named after Goete ]. Retrieved 23.09.2013 from: <http: // www. ilt - frankfurt. de / academic content. php> (in German). 